\title{
The Influence of Administrative Monopoly on Economic Development__An Empirical Study Based on Vector Error Correction Model
}

\author{
Zhao Xiaoge $^{1} \&$ Zhong Shihu ${ }^{1}$ \\ ${ }^{1}$ Hunan University of Science and Technology, Xiangtan, Hunan 411201, China \\ Correspondence: Zhongshihu, Hunan University of Science and Technology, Xiangtan, Hunan 411201, China. \\ E-mail:1010776114@qq.com
}

Received: March 23, 2017

Accepted: May 14, 2017

Online Published: May 17, 2017

doi:10.5539/ijbm.v12n6p182

URL: https://doi.org/10.5539/ijbm.v12n6p182

\begin{abstract}
As a unique form of China's transition economy, the impact of administrative monopoly on economic development can not be ignored. Analyzing the data from 1990 to 2015, this paper investigates the relationship between administrative monopoly and economic development based on Vector Error Correction Model (VEC)model. The results show that there is a long - term equilibrium relationship between administrative monopoly and economic development. In the long run, the administrative monopoly has obvious obstructive effect on economic development. The hardest part, as well as the emphasis in China's economic reform will be how to separate the government from state-owned enterprises and eliminate administrative monopoly.
\end{abstract}

Keywords: administrative monopoly, economic development, vector error correction model

\section{Introduction}

With a special economic system, the socialist market economy, administrative monopoly seems to be unavoidable in China. Government relying on state-owned enterprises while state-owned enterprises being backed by government, this has long been a typical feature of China's economy and is also a difficulty in the reform. At present, the administrative monopoly has become the largest institutional barriers in China's sustained and rapid economic growth.

Administrative monopoly is a unique form of China's transition economy. Domestic and foreign scholars have made a lot of meaningful research on the impact of administrative monopoly on economic growth. The scope of these literatures mainly focuses on three aspects: Firstly, the direct influence on economic growth made by administrative monopoly, including regional administrative monopoly (Lu Ming, Chen Zhao, 2009) and the impact of industrial administrative monopoly on economic growth (Yu Liangchun, Zhang Wei, 2010). Secondly, the indirect impact of administrative monopoly on factors of economic growth, such as the impact of regional administrative monopoly on investment competition (Young, 2000; Edin, 2003; Guo Qingwang, Zhao Xujie, 2012), the impact on market integration (Li Zhen, 2012), the impact on export enterprises (Chen Lin, 2011), the impact on technological progress (Fu Qiang, 2008); and the impact of industry administrative monopoly on the distribution of income (Zhang Yuan, 2011; Yang Lin, Hao Han, 2013), the impact on resource allocation efficiency (Abed and Davoodi, 2000). Thirdly, the dynamic evolution of the influence of administrative monopoly on economic growth, which has less research, and only a few studies have sorted out the changes in nationalization of the economy and administrative monopoly system (Chen Lin, Zhu Weiping, 2012), and pointed out the conditions and basis of regional economic growth promoted by administration monopoly ( $\mathrm{Fu}$ Qiang, Qiao Yue, 2011). In addition, other related researches also examine the impact of institutional factors on economic growth from the aspects of marketization(Jin Tao, 2007), property rights system(Zheng Ruogu, 2010) ${ }^{[15]}$ and economic openness(Pan Xiangdong, 2005).

The existing literatures play a significant role in this study. However, there still exist the following limitations: Some literatures illustrate the impact on economic growth caused by administrative monopoly only from one aspect, lacking a more macro-perspective and systematic analysis. Or it misses some variables, which will resulted in empirical bias and affect the validity of policy recommendations.Or it does not test the dynamic relationship between administrative monopoly and economic growth, thus failing to tell the distinction between 
long-term and short-term effects. Extending the existing researches, this paper constructs the theoretical model, and uses the Vector Error Correction Model (VEC) to study the relationship between administrative monopoly and economic development mainly in the following three ways: Firstly, the empirical model established with Least Squares and Simple Differential Variables is improved, and the VEC model is used to avoid the "pseudo-regression" and multi-collinearity; Secondly, the introduction of error correction ensures that the variable level of the information will not be missed; Thirdly, the detailed robustness test is done for the empirical analysis to ensure the rationality of the econometrics model.

\section{Research Methods and Data Sources}

\subsection{Research Methods}

The so-called administrative monopoly, that is the government regulation coupled with market monopoly, or it means administrative power supports and protects state-owned enterprises to form and maintain the monopoly (Zhang Shuguang, 2007) ${ }^{[17]}$. Based on the definition of administrative monopoly in the previous literature, this paper chooses five dimensions including Financial Incentive (FI), Government Influence (GI), Government Regulation (GR), Labor Price Distort (LPD), State-owned Enterprise Scale (SEC) to construct the initial measurement model as follows:

$$
I G_{t}=\alpha+\beta_{1} \mathrm{~F} I_{t}+\beta_{2} G I_{t}+\beta_{3} G R_{t}+\beta_{4} L P D_{t}+\beta_{5} S E C_{t}
$$

Because the administrative monopoly has a certain lag to the economic development, the endogenous variables of the model may affect each other, and then construct the Vector Autoregressive(VAR) model. The VAR model is based on the statistical properties of the data. It is an unstructured multivariate model constructed by using the endogenous variable as the explanatory variable and the lag value of all the endogenous variables as explanatory variables. It can effectively analyze and forecast a number of relevant economic indicators. The general expression is as follows:

$$
y_{t}=A_{1} y_{t-1}+A_{2} y_{t-2}+\cdots+A_{n} y_{t-n}+B x_{t}+\varepsilon_{t}
$$

Among them, $y_{t}$ is the $\mathrm{k}$-dimensional endogenous variable vector, $x_{t}$ is the 1-dimensional exogenous variable vector, $\mathrm{n}$ is the lag order, and the number of samples is $\mathrm{T}$. $k \times k$ dimensional matrix A and $k \times l$ dimension matrix $\mathrm{B}$ are the coefficient matrices to be estimated. $\varepsilon_{t}$ is a k-dimensional perturbation vector.

Substituting the administrative monopoly and economic development of the relevant variables, the vector autoregressive model matrix with the endogenous variable laged $\mathrm{n}$ order is given as follows:

$$
\left(\begin{array}{l}
\mathrm{IG}_{\mathrm{t}} \\
\mathrm{FI}_{\mathrm{t}} \\
G I_{\mathrm{t}} \\
\mathrm{GP}_{\mathrm{t}} \\
\mathrm{LPD}_{\mathrm{t}} \\
\mathrm{SEC}_{\mathrm{t}}
\end{array}\right)=\mathrm{A}_{1}\left(\begin{array}{l}
\mathrm{IG}_{\mathrm{t}-1} \\
\mathrm{FI}_{\mathrm{t}-1} \\
G I_{\mathrm{t}-1} \\
\mathrm{GP}_{\mathrm{t}-1} \\
\mathrm{LPD}_{\mathrm{t}-1} \\
\mathrm{SEC}_{\mathrm{t}-1}
\end{array}\right)+\mathrm{A}_{2}\left(\begin{array}{l}
\mathrm{IG}_{\mathrm{t}-2} \\
\mathrm{FI}_{\mathrm{t}-2} \\
G I_{\mathrm{t}-2} \\
\mathrm{GP}_{\mathrm{t}-2} \\
\mathrm{LPD}_{\mathrm{t}-2} \\
\mathrm{SEC}_{\mathrm{t}-2}
\end{array}\right)+\cdots+\mathrm{A}_{\mathrm{n}}\left(\begin{array}{l}
\mathrm{IG}_{\mathrm{t}-\mathrm{n}} \\
\mathrm{FI}_{\mathrm{t}-\mathrm{n}} \\
G I_{\mathrm{t}-\mathrm{n}} \\
\mathrm{GP}_{\mathrm{t}-\mathrm{n}} \\
\mathrm{LPD}_{\mathrm{t}-\mathrm{n}} \\
\mathrm{SEC}_{\mathrm{t}-\mathrm{n}}
\end{array}\right)+\left(\begin{array}{l}
\mathrm{x}_{1 \mathrm{t}} \\
\mathrm{x}_{2 \mathrm{t}} \\
\mathrm{x}_{3 \mathrm{t}} \\
\mathrm{x}_{4 \mathrm{t}} \\
\mathrm{x}_{5 \mathrm{t}} \\
\mathrm{x}_{6 \mathrm{t}}
\end{array}\right)+\left(\begin{array}{l}
\varepsilon_{1 \mathrm{t}} \\
\varepsilon_{2 \mathrm{t}} \\
\varepsilon_{3 \mathrm{t}} \\
\varepsilon_{4 \mathrm{t}} \\
\varepsilon_{5 \mathrm{t}} \\
\varepsilon_{6 \mathrm{t}}
\end{array}\right)
$$

If the time series variable we select is stable, it can directly apply the VAR model to estimate. If there is a non-stationary variable, we must examine the cointegration relationship. According to Granger's theorem, a number of non-stationary variables with cointegration relations must have error correction model expression. Therefore, when the cointegration relationship exists, the VEC model (It can also be called a VAR model with cointegration constraints) is used. The VEC model can be deduced from the autoregressive distribution hysteresis model.

In the case where the exogenous variables is not included and the time series variables exist a cointegration relationship, the formula (2) is rewritten as:

$$
\Delta y_{t}=\alpha \beta^{\prime} y_{t-1}+\sum^{n-1} \Gamma_{i} \Delta y_{t-i}+\varepsilon_{t}
$$

Since the unbalanced error of the non-stationary variābles with the cointegration relationship is stable, the error term of each equation is stable, and the vector error correction model can be expressed as: 


$$
\Delta y_{t}=\alpha e c m_{t-1}+\sum_{i=1}^{n-1} \Gamma_{i} \Delta y_{t-i}+\varepsilon_{t}
$$

All equations on the above are error correction models, ecm ${ }_{t 1}=\beta^{\prime} y_{t 1}$ is an error correction item, reflecting the long-term equilibrium relationship between variables; The coefficient vector $\alpha$ represents the adjustment speed when the equilibrium relationship among the variables deviates from the long-term equilibrium state, then its adjustment is restored to the equilibrium state; the regression coefficients of all the differential terms as explanatory variables represent the effect of the short-term variation of each variable on the short-term variation of the explanatory variables; the hysteresis difference term that has no significant effect can be eliminated.

To sum up, we can build the administrative monopoly and economic development of the VEC model as follows:

$$
\begin{aligned}
& \Delta G D P_{t}=\sum_{i=1}^{n-1} \alpha_{i} \Delta G D P_{t-i}+\sum_{i=1}^{n-1} \beta_{i} \Delta F I_{t-i}+\sum_{i=1}^{n-1} \chi_{i} \Delta G I_{t-i}+\sum_{i=1}^{n-1} \delta_{i} \Delta G R_{t-i}+ \\
& \sum_{i=1}^{n-1} \gamma_{i} \Delta L P D_{t-i}+\sum_{i=1}^{n-1} \lambda_{i} \Delta S E C_{t-i}+\varphi e c m_{t-1}+\varepsilon_{t}
\end{aligned}
$$

\subsection{Variable Selection and Data Source}

Based on the above model, this paper measures the influence of administrative monopoly on economic development. Per capita GDP is used as Economic development indicator and 1990 is used as basic period to eliminate inflation. According to its definition, the administrative monopoly is divided into government behavior and state-owned enterprise monopoly. Government behavior is measured by Fiscal Incentives, Government Influence, and Government Regulation. State-owned enterprises monopoly is measured by Labor Price Distortions and State-owned Enterprises Scale. Data come from the "China Statistical Yearbook", "China Financial Yearbook" and "China Industrial Statistics Yearbook". The data range used is from 1990 to 2015, we take the natural logarithmic processing of the variable data except FI to eliminate the influence of heteroscedasticity, and make the data smoother. They are recorded as: $L n G D P_{t}, F I_{t}, L n G I_{t}, L n G R_{t}, L n L P D_{t}$ and $\operatorname{LnSEC}_{t}$.

Among them, the variables are defined as follows:

Table 1. Variable Definition Table

\begin{tabular}{llll}
\hline $\begin{array}{l}\text { Administrative } \\
\text { Monopoly }\end{array}$ & $\begin{array}{l}\text { Variable } \\
\text { Name }\end{array}$ & Variable Meaning & Calculation Method \\
\hline Government Behavior & GDP & $\begin{array}{l}\text { Per Capita Gross } \\
\text { Domestic Product } \\
\text { Financial Incentives }\end{array}$ & From the "China Statistical Yearbook" \\
& FI & $\begin{array}{l}\text { (Fiscal Expenditure - Fiscal Revenue) / Fiscal } \\
\text { Revenue }\end{array}$ \\
& GI & $\begin{array}{l}\text { Government Influence } \\
\text { Giscal Expenditure / Gross Domestic Product }\end{array}$ \\
State-owned & GR & $\begin{array}{l}\text { Labor Price Distortion } \\
\text { Enterprise Monopoly }\end{array}$ & $\begin{array}{l}\text { State-owned Average Nominal Wage / Average } \\
\text { Wage of Workers on Duty }\end{array}$ \\
& SEC & $\begin{array}{l}\text { State-owned Enterprises } \\
\text { Scale }\end{array}$ & $\begin{array}{l}\text { State-owned Industrial Output Value / Total } \\
\text { Industrial Output Value }\end{array}$ \\
\hline
\end{tabular}

\section{Empirical Study and Results Analysis}

\subsection{Stability Test}

Since the data of many economic variables in real life are usually non-stationary, this paper do unit root test to determine the stability of the variables and single integral order at first. Moreover, the variables can only have a cointegration relationship with the same order of the single integral. The optimal lag order is determined by Akaike Information Criterion (AIC) and Schwarz Criterion (SC) to ensure the correctness of the test results. Using the Stata13.0 to do the ADF test on the time series data, the results are shown in Table 2. 
Table 2. Unit Root test results

\begin{tabular}{|c|c|c|c|c|}
\hline Variable & $(\mathrm{c}, \mathrm{t}, \mathrm{n})$ & ADF Statistic & P Value & Conclusion \\
\hline \multirow[t]{2}{*}{$\operatorname{LnGDP_{t}}$} & $(1,0,0)$ & -1.473 & 0.8381 & Non-stationary \\
\hline & $(1,0,1)$ & -2.018 & 0.8279 & Non-stationary \\
\hline \multirow[t]{2}{*}{$F I_{\mathrm{t}}$} & $(1,0,0)$ & -2.076 & 0.2534 & Non-stationary \\
\hline & $(1,0,1)$ & -2.396 & 0.1429 & Non-stationary \\
\hline \multirow[t]{2}{*}{$\operatorname{Ln} G I_{t}$} & $(1,0,0)$ & -1.532 & 0.3649 & Non-stationary \\
\hline & $(1,0,1)$ & -1.602 & 0.4826 & Non-stationary \\
\hline \multirow{2}{*}{$\operatorname{LnGR} R_{t}$} & $(1,0,0)$ & -0.739 & 0.8364 & Non-stationary \\
\hline & $(1,0,1)$ & -0.932 & 0.7773 & Non-stationary \\
\hline \multirow[t]{2}{*}{$L n L P D_{t}$} & $(1,0,0)$ & -2.060 & 0.2607 & Non-stationary \\
\hline & $(1,0,1)$ & -1.530 & 0.5185 & Non-stationary \\
\hline \multirow[t]{2}{*}{$\operatorname{LnSEC}_{t}$} & $(1,0,0)$ & -1.759 & 0.4008 & Non-stationary \\
\hline & $(1,0,1)$ & -2.298 & 0.1725 & Non-stationary \\
\hline \multirow[t]{2}{*}{$\nabla \operatorname{LnGDP} P_{t}$} & $(1,0,0)$ & -4.623 & 0.0124 & Stationary \\
\hline & $(1,0,1)$ & -3.319 & 0.0141 & Stationary \\
\hline \multirow[t]{2}{*}{$\nabla F I_{t}$} & $(1,0,0)$ & -3.965 & 0.0016 & Stationary \\
\hline & $(1,0,1)$ & -4.185 & 0.0007 & Stationary \\
\hline \multirow[t]{2}{*}{$\nabla \operatorname{LnGI}_{\mathrm{t}}$} & $(1,0,0)$ & -6.22 & 0.0023 & Stationary \\
\hline & $(1,0,1)$ & -6.37 & 0.0079 & Stationary \\
\hline \multirow[t]{2}{*}{$\nabla L n G R$} & $(1,0,0)$ & -5.166 & 0.0001 & Stationary \\
\hline & $(1,0,1)$ & -4.459 & 0.0002 & Stationary \\
\hline \multirow[t]{2}{*}{$\nabla L n L P D_{t}$} & $(1,0,0)$ & -5.655 & 0.0000 & Stationary \\
\hline & $(1,0,1)$ & -3.225 & 0.0186 & Stationary \\
\hline \multirow[t]{2}{*}{$\nabla \operatorname{LnSEC} C_{t}$} & $(1,0,0)$ & -3.913 & 0.0019 & Stationary \\
\hline & $(1,0,1)$ & -3.282 & 0.0157 & Stationary \\
\hline
\end{tabular}

Note. The form $(\mathrm{c}, \mathrm{t}, \mathrm{n})$ represents the constant term, the time trend term and the lag order. Where "c $=1$ " means a constant term, "c $=0$ " means no constant term; where $" \mathrm{t}=1$ " means no trend item, $" \mathrm{t}=0$ " means no trend item; $\mathrm{n}$ indicates the number of lag periods. $\nabla$ indicates the difference.

From the test results, we found that the $L n G D P_{t}, F I_{t}, L n G I_{t}, L n G R_{t}, L n L P D_{t}$ and $L n S E C_{t}$ 's ADF values are greater than the critical value of $1 \%$ and $5 \%$ significant level, indicating that the six variables exist the unit root,so they are non-stationary. And the corresponding differential sequences of ADF values are less than the critical value, indicating that the differential sequence of variables is stationary, which can determine that the six variables are first-order single integer.

\subsection{Cointegration Test}

The study of Engel and Granger (1987) showed that the linear combination of two or more non-stationary sequences can have a property that does not change over time ,and they can be stationary, which means there is a cointegration relationship among these variables. As the variables selected in this paper, the $L n G D P_{t}, F I_{t}, L n G I_{t}, L n G R_{t}, L n L P D_{t}$ and $L n S E C_{t}$ are all first-order single integer, and meet the basic conditions of cointegration test, so it can be cointegration analysised. There are two commonly used cointegration test methods, E-G two-step method based on residual equation of regression equation and JJ test based on regression coefficient. The first method is generally used to test the relationship between two variables, and the second method is more suitable for the relationship among multiple variables to test. So this paper uses 
$\mathrm{JJ}$ cointegration test Johansen and Juselius proposed. The test results are shown in Table 3.

Table 3. Cointegration test results

\begin{tabular}{llllll}
\hline Original & Alternative & Trace & $5 \%$ Critrical & Max & 5\% Critrical \\
Hypothesis & Hypothesis & Statistic & Value & Statistic & Value \\
\hline Zero & One & 148.1257 & 94.15 & 60.9032 & 39.37 \\
Up to One & Two & 87.225 & 68.52 & 35.6014 & 33.46 \\
Up to Two & Three & 51.6211 & 47.21 & 27.6259 & 27.07 \\
Up to Three & Four & 23.9952 & 29.68 & 12.5087 & 20.97 \\
Up to Four & Five & 11.4865 & 15.41 & 8.4704 & 14.07 \\
\hline
\end{tabular}

The maximum eigenvalue test and trace test results show that at a significant level of $5 \%$, the original hypothesis that has no and up to two covariance equations are rejected while those has up to three and up to four covariance equations are accepted. According to the normalization of the cointegration coefficient, a cointegration equation that can reflect the relationship among variables more specifically is selected as follows:

$$
\begin{aligned}
& \operatorname{LnGDP}_{t}=0.0373 F I_{t}-0.3666 \operatorname{LnGI}_{t}-0.3966 \operatorname{LnGR} R_{t}-22.6038 \operatorname{LnLPD}_{t} \\
& -0.4361 \operatorname{LnSEC}_{t}-92.8195+e \mathrm{~cm}
\end{aligned}
$$

Cointegration analysis shows that from 1990 to 2015, administrative monopoly has a stable and effective long-run equilibrium effect on economic development. In the long run, Gross Domestic Product (GDP) is negatively correlated with Government Influence(GI), Government Regulation(GR), Labor Price Distortions(LPD) and State-owned Enterprises Scale(SEC), and is positively related to Fiscal Incentives(FI). The elasticity of GDP to GI is 0.3666 , which means that one percent change in GI will lead to a reversal of 0.3666 percentage points of GDP. Similarly, every per percentage change of GR, LPD and SEC will drive GDP, respectively, change by $0.3966,22.6038,0.4361$ percentage points; FI per percentage change, will lead to changes in GDP by 0.0379 percentage points, and according to this coefficient, its impact on economic development is relatively small. This shows that GI, GR, LPD and SEC will slow the pace of economic development, and FI will accelerate economic development.

\subsection{VEC Model}

Relevant variables have a cointegration relationship between the economic development and the the administrative monopoly, and the variables are not stable, so the VEC model can be applied. First, we test the smoothness of the model. It can be seen from the test that the VEC model is stationary without the rooting of the unit circle. The estimation results of the VEC model are shown in Table 4.

\begin{tabular}{|c|c|c|c|c|c|c|}
\hline Variables & $\nabla \operatorname{Ln} G D P_{\mathrm{t}}$ & $\nabla F I_{t}$ & $\nabla \operatorname{Ln} G I_{t}$ & $\nabla \operatorname{Ln} G R_{t}$ & $\nabla L n L P D_{t}$ & $\nabla \operatorname{LnSEC} C_{t}$ \\
\hline$\nabla\left(\operatorname{LnGDP} P_{t}(-1)\right)$ & $\begin{array}{l}0.434327 \\
(0.333362)\end{array}$ & $\begin{array}{l}28.08283 \\
(63.71376)\end{array}$ & $\begin{array}{l}-0.375701 \\
(-0.934057)\end{array}$ & $\begin{array}{l}-5.165128 \\
(-5.424076)\end{array}$ & $\begin{array}{l}-0.024903 \\
(-0.193008)\end{array}$ & $\begin{array}{l}-0.931019 \\
(-2.419078)\end{array}$ \\
\hline$\nabla\left(F I_{t}(-1)\right)$ & $\begin{array}{l}0.001610 \\
(0.001918)\end{array}$ & $\begin{array}{l}0.411780 \\
(0.366539)\end{array}$ & $\begin{array}{l}-0.007203 \\
(0.005374)\end{array}$ & $\begin{array}{l}0.038690 \\
(0.031204)\end{array}$ & $\begin{array}{l}-0.001941 \\
(-0.001110)\end{array}$ & $\begin{array}{l}-0.000775 \\
(0.013916)\end{array}$ \\
\hline$\nabla\left(\operatorname{Ln} G I_{t}(-1)\right)$ & $\begin{array}{l}-0.060958 \\
(1.095921)\end{array}$ & $\begin{array}{l}21.90108 \\
(18.33281)\end{array}$ & $\begin{array}{l}0.945626 \\
(0.268763)\end{array}$ & $\begin{array}{l}0.885100 \\
(1.560708)\end{array}$ & $\begin{array}{l}0.101819 \\
(0.055536)\end{array}$ & $\begin{array}{l}1.113216 \\
(0.696058)\end{array}$ \\
\hline$\nabla\left(\operatorname{Ln} G R_{t}(-1)\right)$ & $\begin{array}{l}-0.018065 \\
(1.023106)\end{array}$ & $\begin{array}{l}1.668395 \\
(4.416029)\end{array}$ & $\begin{array}{l}0.041079 \\
(0.064739)\end{array}$ & $\begin{array}{l}0.188019 \\
(0.375945)\end{array}$ & $\begin{array}{l}0.007155 \\
(0.013377)\end{array}$ & $\begin{array}{l}-0.000027 \\
(0.167667)\end{array}$ \\
\hline$\nabla\left(\operatorname{LnLPD} D_{t}(-1)\right)$ & $\begin{array}{l}-0.238068 \\
(2.357761)\end{array}$ & $\begin{array}{l}-5.940222 \\
(68.37698)\end{array}$ & $\begin{array}{l}-0.516695 \\
(1.00242)\end{array}$ & $\begin{array}{l}-1.642835 \\
(5.821065)\end{array}$ & $\begin{array}{l}-0.234017 \\
(0.207134)\end{array}$ & $\begin{array}{l}-4.668113 \\
(2.59613)\end{array}$ \\
\hline$\nabla \operatorname{LnSEC}(-1))$ & $\begin{array}{l}-0.003089 \\
(2.031806)\end{array}$ & $\begin{array}{l}-9.214256 \\
(6.078921)\end{array}$ & $\begin{array}{c}-0.014052 \\
(0.089118)\end{array}$ & $\begin{array}{l}-0.504413 \\
(0.5175103)\end{array}$ & $\begin{array}{l}0.034136 \\
(0.018415)\end{array}$ & $\begin{array}{l}-0.1489752 \\
(0.230804)\end{array}$ \\
\hline
\end{tabular}

Table 4. VEC model estimation results 


\begin{tabular}{|c|c|c|c|c|c|c|}
\hline Error Correction Item & $\begin{array}{l}-0.0378366 \\
(-2.0408139)\end{array}$ & $\begin{array}{l}-13.67679 \\
(-7.80053)\end{array}$ & $\begin{array}{l}-0.003645 \\
(-2.114357)\end{array}$ & $\begin{array}{l}-1.163075 \\
(-1.664075)\end{array}$ & $\begin{array}{l}-0.023198 \\
(-1.023630)\end{array}$ & $\begin{array}{l}-0.330876 \\
(-3.296169)\end{array}$ \\
\hline R-squared & & 0.586163 & & AIC & & -14.73846 \\
\hline Adj R-squared & & 0.437289 & & HQIC & & -14.2926 \\
\hline DW & & 2.026761 & & Log Likehood & & 193.0154 \\
\hline
\end{tabular}

Note: Standard deviation in parentheses

It can be seen from the test results that the error correction coefficient is negative and the significance level is more than $1 \%$, which indicates that there is a reverse correction mechanism in the economic development, and which further validates the long-run equilibrium relationship among the variables. It is also known from the estimated results: (1) The increase of GI, GR, LPD and SEC will result in reduction of GDP; (2) An increase of FI will result in increase of GDP; (3) The flexibility of these variables is large, indicating that the role of administrative monopoly on economic development is very significant. The DW value in the VEC model is 2.026761 , which is greater than 5\% significant level on the lower limit, and less than the upper limit ,it indicates that the model does not have sequence correlation and pass the robustness test.

\section{Research Conclusion and Enlightenment}

Based on the VEC model, this paper examines the relationship between administrative monopoly and economic development and draws some conclusions: (1) In the long run,there is a stable and effective balance among the GDP and the Fiscal Incentive, the Government Influence, the Government Regulation, the Labor Price Distortions and the State-owned Enterprises Scale.Among them GI, GR, LPD, SEC will hinder economic development while FI will promote economic development. The order of their impact is: LPD, SEC, GR, GI, FI. (2)In the short term, GI, GR,LPD, SEC have a significant impact on economic development, and the impact of FI on economic development is less significant.

The research of this paper shows that the administrative monopoly formed by the government behavior and the monopoly of the state-owned enterprises has obvious obstacle to the development of China's economy. Although the Financial Incentive can promote the economic development, its role is weak and there is a certain lag. In the long run, in order to enable economy to have a long-term and stable development, it is essential to separate the government from state-owned enterprises, eliminate the administrative monopoly, reduce the access threshold for private enterprises, ensure all private enterprises and state-owned enterprises are competing fairly, release the vitality of the private economy, and make the full use of market.

\section{Acknowledgements}

It is supported by Hunan Provincial Innovation Foundation For Postgraduate "(Grant No.CX2016B508).

\section{References}

Abed, G., \& Davoodi, H. (2000). Corruption,Structural Reforms,and Economic Performance in the Transition Economics. International Monetary Fund, IMF Working Paper WPP00P132. https://doi.org/10.5089/9781451855371.001

Chen, L. (2011). A Study on the Economic Performance of China's Administrative Monopoly in the Transitional Period. Guang Zhou: Jinan University.

Chen, L., \& Zhu, W. P. (2012). Economic Nationalization and the Development of Administrative Monopoly System:Study on Economic History From the Perspective of Institutional Change. Journal of Finance and Economics, 3, 49-58.

Chu, M., Jin, T. (2013). The Government Paradox, Monopoly of State-owned Enterprises and IncomeGap-An Empirical Test Based on the Characteristics of China's Transformation. China Industrial Economics, 2, 18-30.

Edin, M. (2012). State Capacity and Local Agent Control in China:CCP Cadre Management from a Township Perspective. China Quarterly, 173(1), 35-52.

Fu, Q. (2008). Regional Administrative Monopoly, Technological Progress and Extensive Economic Growth: An Empirical Study Based on China's Technical Progress from 1978 to 2006. Economic Science, 5, 69-80.

Fu, Q., Qiao, Y. (2011). How Does Government Competition Promote Rapid Economic Growth in China: A 
Further Discussion on the Relationship between Market Segmentation and Economic Growth. The Journal of World Economy, 7, 43-63.

Guo, Q. W., Zhao, X. J. (2012). Local Government Investment Competition and Economic Cycle Fluctuation. The Journal of World Economy, 5, 3-21.

Jin, T. (2007). A Research View to Reveal the Puzzle of the Relationship between Institution and Growth-On the Basis of an Empirical Analysis on China's Economic Transition and Economic Growth (1978-2004). Economist, 5, 18-26.

Li, Z. (2012). An Analysis of the Impact Mechanism of China's Market Integration Process Based on the Perspective of Regional Administrative Monopoly. Review of Economy and Management, 5, 37-44.

Lu, M., Chen, Z. (2009). Fragmented Growth: Why Economic Opening May Worsen Domestic Market Segmentation? Economic Research Journal, 3, 42-52.

Pan, X. D., Liao, J. Z., \& Lai, M. Y. (2005). An Empirical Research on the Relationship of Economic Institutional Arrangement, International Trade and Economic Growth. Economic Research Journal, 11, $57-67+124$.

Yang, L., Hao, H. (2013). Study on the Realization Mechanism and Path of Equitable Distribution of Income under the Framework of Public Finance. Review of Economy and Management, 2, 109-113.

Young, A. (2000). The Razor's Edge: Distortions and Incremental Reform in China. Quarterly Journal of Economics, 115(4), 1091-1135. https://doi.org/10.1162/003355300555024

Yu, L. C., \& Zhang, W. (2010). Intensity and Efficiency Loss of Industry Administrative Monopoly in China. Economic Research Journal, 3, 16-27+39.

Zhang, S. (2007). Expand openness and anti-administrative monopoly. Decision and Information, 3, 18-23.

Zhang, Y. (2011). The Income Distribution Effect of Chinese Industrial Monopoly. Economic Review, 4, $54-62+123$.

Zheng, R. G., Gan, C. H., \& Yu, D. F. (2010). The Industrial Structure and Institutional Effects of Economic Growth in China's Transition Period: An Analysis Based on a Stochastic Frontier Model. China Industrial Economics, 2, 58-67.

\section{Copyrights}

Copyright for this article is retained by the author(s), with first publication rights granted to the journal.

This is an open-access article distributed under the terms and conditions of the Creative Commons Attribution license (http://creativecommons.org/licenses/by/4.0/). 